\title{
Strategies for Instilling Educational Values in Islamic Boarding School (IBS)
}

\author{
Munirul Abidin \\ Department of Islamic Education Management, Faculty of Islamic Education, Universitas Islam Negeri Maulana Malik Ibrahim \\ Malang, Indonesia
}

Received May 20, 2020; Revised July 20, 2020; Accepted August 10, 2020

\section{Cite This Paper in the following Citation Styles}

(a): [1] Munirul Abidin, "Strategies for Instilling Educational Values in Islamic Boarding School (IBS)," Universal Journal of Educational Research, Vol. 8, No. 9, pp. 4028- 4035, 2020. DOI: 10.13189/ujer.2020.080928.

(b): Munirul Abidin (2020). Strategies for Instilling Educational Values in Islamic Boarding School (IBS). Universal Journal of Educational Research, 8(9), 4028 - 4035. DOI: 10.13189/ujer.2020.080928.

Copyright $\bigcirc 2020$ by authors, all rights reserved. Authors agree that this article remains permanently open access under the terms of the Creative Commons Attribution License 4.0 International License

\begin{abstract}
Indonesia's national education goals are to form intelligent, civilized, and dignified people to live in society and succeed in the future. Therefore, every educational institution in Indonesia must teach specific values that are believed to deliver its students to be the people they aspired. This study aims to describe the values of educational organizations embedded to students at Darussalam Islamic Boarding School (DIBS) in Indonesia and their cultivating strategies. The reason for choosing this institution to be researched is that it has a long experience and has created many qualified and successful people at both national and international levels - the survey conducted with a qualitative approach. Data are collected through observation, documentation, and interviews with several caregivers, teachers, students, and administrators of the institution. Before being analyzed, the interview data are transcribed, then read repeatedly to find the exact meaning behind the words. Data validation is done by triangulation techniques, both by source and method triangulation. This study found five values that serve as a foundation for the institution to carry out the entire process of organizational activities. These values are embedded with five strategies integrated into all students as members of the organization. This research contributes to finding values that should be instilled in students in educational institutions to become reliable and responsible individuals to succeed in the future. The strategy of instilling educational values found in this study also gives a new color in the world of education. It can become a role model for other institutions in inculcating educational values.
\end{abstract}

Keywords Educational Values, Education Strategy, Islamic Boarding School, Values Cultivation, Educational Organization

\section{Introduction}

Research on strategies for instilling the educational organization values received attention from researchers [1], [2]. They see that the educational organization values essential to teaching in the members of the organization [3], to make them have the same vision and mission in running the organization. But the views on what values applied to educational organizations, and what strategies to instill these values in their members or students still debated. Some people see that the values to teach must be universal. These include caring, compassion, empathy, honesty, and fairness [4], and others see it to be specified under the vision of the institution. Some researchers recognize the importance of religious values [5], while others proposed other values [6]. Researchers also have not agreed on how to instill these values in the members of the educational organization. Some see that the inculcation of organizational values done through a process of teaching and role models [7], while others see through the leadership role [8], [9]. There is still no agreement from the researchers in this matter. Further research on this issue still needs to carry out to provide insight more broadly about the values of educational organizations and their 
cultivation strategies.

Organizational values have many meanings [10], [11]. Pettigrew [12] defines that organizational values are the system of such publicly and collectively accepted meanings operating for a given group at a given time. For $\mathrm{him}$, the essence of organizational values is on its values system. By the system, values can be transformed and shared with the member of the organization [13]. Values can't be understood only from the component of the organization, such as strategy, structure, and organizational system. Still, it must be distinguished from within an organization because organizational values are very abstract, exclusive, and hidden behind the shared meaning [14]. Two types of shared meanings alive in the member of the organization are beliefs and values. Belief is a fundamental assumption of life and how life is going on, and values are a fundamental assumption of something ideal that must be reached and defended [15].

Values are essential in organizational life [16]. It will guide them to act according to the mission of the organization. Davis [17] stated that organizational values are the pattern of shared beliefs that give the members of an institution meaning and provide them with the rules for behavior in their organization. Organizational values are ways of life, acting, feeling, and thinking, which are learned by a group of people rather than biologically determined [18].

As ways of life, organizational values must be learned from generation to generation in the organization [19]. Values are the pattern of shared underlying assumptions that the group learned as it solved its problems of external adaptation and internal integration, that worked well enough to be considered valid. Therefore, the values must be taught to new members as the correct way to think and feel concerning the organization [20], [21].

Developing organization values need a long process. Value reflects an institution's unique code of behavior, language, customs, and manners of operating. It distinguishes the institution from other entities and can help them determine organizational success or failure [22].

Organizational values do not only exist in the business organization, but all aspects of the human organization included in the educational realm [23]. Some researches on this field conducted to investigate its impact on building a better life of an organization [24], [25]. One of the educational institutions that have particular organizational values in Indonesia is Islamic Boarding School (IBS), with a long history in Indonesia. One of the factors that make IBS survive today is they have some organizational values. Those values are learned from generation to generation through Kyai as a leader of IBS [26], [27]. IBS was able to produce significant output like the amount of high quality of ulama' who has a sincerity to perform Islamic teaching toward Muslims [28] and bring religious and scientific tasks besides its life tradition taught from generation to generation. The question is, what are the organizational values developed by Islamic Boarding School to make them survive today? How does the organization keep, design, and cultivate those values as the soul of their organization?

\section{Method}

This study employs a qualitative approach by a single case study design [29]. This research was conducted at the Darussalam Islamic Boarding School (DIBS) located at Ponorogo, East Java, Indonesia, which was founded in 1926. DIBS is known as the modern Islamic boarding school because it implements a modern education system. DIBS is also known as an educational institution that implements education with discipline so that the alumni of this IBS have a tenacious and disciplined character [30]. The data collected through observation, interviews, and documentation. Interviews conducted with several caregivers, teachers, administrators, and students of DIBS. Five caregivers, five teachers, five administrators, and five students were selected as informants in this study. Data mining was done naturally using in-depth interview techniques [31]. Each informant interviewed for about 30-60 minutes - the issue of the values of the school organization and its cultivating strategy. The researcher uses interview guidelines which consist of five questions below:

- What are the educational values taught to students in this educational institution?

- How do those values affect the lives of students at boarding school?

- What efforts have been made by the institution to prepare students to accept those values of the organization?

- What conditions students must have to take, accept, and implement these values in their lives at boarding school.

- Are there any particular strategies for embedding organizational values to students?However, in practice, those questions can multiply and are not limited to the five questions, until the researcher finds a satisfying answer.

To check the data validity, the researcher consulted the results of the study with the participants using source triangulation techniques and methods [31]. Researchers crosscheck data with different sources and different approaches. Therefore, after conducting interviews with key informants, the researcher checks the same question to different sources, both at the same level and the level below it - data crosschecking also done using various methods. If the researcher finds new statements from the interview results, the researcher sees the compatibility with the practice in the field, so that the data obtained can be justified [32].

Data analysis performed following general qualitative research procedures, starting with data collection, coding, 
classification, reduction, and inference [33]. The coding process begins with transcribing first. The analysis process continued with multiple readings to find important themes of each word or sentence. Emerging issues are repeatedly reviewed to be organized in one category as our knowledge of research themes increases. When we consider the results of our readings final, and the categories found, we arrange them to look for interrelationships between categories. Eventually, we organize in order, which ones should take precedence and which ones are placed in the section end so that it is arranged systematically [34].

\section{Result and Discussion}

\subsection{DIBS Educational values: Five Souls}

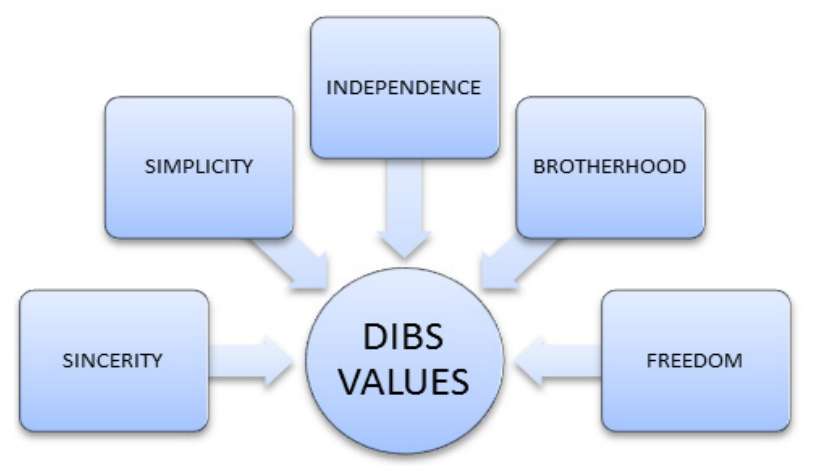

Figure 1. Five souls values of DIBS

Each IBS has its values taught to its organization's members as the stage of their lives in the organization and their futures life, primarily when they have grown up and joined on the broader community. Those values are instilled in students through a long process and planned strategy through activities held at school.

As a modern organization, DIBS has several values taught to its organization members, teaching, non-teaching staff, and students, from generation to generation. The values are known as "Panca Jiwa" (five souls). Those five souls are sincerity/honesty, modesty, self-sufficient, Islamic brotherhood, and freedom. The lives of organizational members must reflect these values in conducting their activities, and all tasks are given to them.

Sincerity. For DIBS, sincerity is the first and most important value that they must cultivate it to the students. Sincerity, in this context, means that all jobs are done just for the worship of God (Allah). In this boarding school, all members of the organization must do their job sincerely, although the organization did not pay them any money.

Leaders, teachers, and students who handle a particular job in the organization have to sincerely do their job without asking for any payment from the organization. But they have to sacrifice themself and their money if the organization needs them to do it. Sincerity became a significant value in this boarding school. By this value, the organization can run its activities at low cost and good results because every member of the organization wants to do the best without any pretensions. Even they must be sincerely punished if they make mistakes in carrying out their duties.

This finding is in line with several studies that show that the value of sincerity and honesty are the foundation for building trust [35], and sincerity could form a valuable basis for the development of institutions and other evaluation bodies [36].

Simplicity. For IDBS, simplicity or modesty means not be passive and inferior but living in the middle. Simplicity becomes a significant value for them because, by simplicity principle, there are strongness, ability, and the patient to face life. In modesty style, the greatness of the soul is revealed.

Modesty for them is the capital for success. When they have an idea, this value will play an essential role in reaching it. They believe in modesty; there is a power to achieving something impossible.

This finding supports previous research revealed that modesty value closely relates to self-efficacy [37]. Someone who holds the value of simplicity will affect his behavior and attitude towards others. Someone who behaves modestly will respect others more and does not want to be seen as extravagant by others to act naturally in all activities [38].

Independence. For DIBS, independence means self-reliance or the ability to help yourself. Students need to be self-reliant because they stay so far from their parents or family. They have to take care of themselves in their daily lives. Independence is an essential soul for students to take care of their own lives and not depend on others.

The DIBS emphasizes this value to make the students live independently, especially when they live in the school dormitory. Independence makes them more mature and able to determine their steps and ideas towards success. This finding is in line with several previous studies that explain the importance of the value of independence and make it the final orientation of most parents in educating their children [39]. However, opinion differences among parents regarding self-reliance and independence [40] depend on people's culture [41].

Islamic brotherhood. DIBS strongly emphasizes the value of Islamic brotherhood to their students. Therefore, this institution does not question ethnic and national differences. All students, from any ethnicity and nationality, must be able to merge into one. Group differences should also not raise in organizations. To live in the boarding school with harmony, they have to make sense of Islamic brotherhood, a sense of unity and mutual support. They have the joy of being together with this religious feeling of fellowship (fraternity), not only in the boarding school but until they graduate. It even affects the unity of the people in society. 
Because of this principle, in DIBS, all people can enter without seeing their ethnicity, nationality, race, and organization. This principle can blend all differences in one container. DIBS becomes like a melting pot that can unite differences into one without changing their character. This finding is supported by several previous studies that explain that the value of brotherhood can merge differences in class, gender, and fraternalism [42]. Four factors characterize strong brotherhood values - solidarity, shared social experiences, belonging, and accountability.

Freedom. DIBS emphasizes its organizational members to hold the value of freedom, which means free to think and act, free to determine the future, free to choose a way of life in society, with an energetic and optimistic attitude toward life. Freedom also means free from foreign/colonial influences (here is a must find the history of the boarding school that is isolated from Western life brought by colonizers). This value, in general, can encourage all students to be themselves without having to follow others. This finding is in line with previous research, emphasizing the importance of the value of freedom of thought to enhance creativity [43], [44] and performance [45].

Several other IBS, which have a genetic relationship with DIBS, internalize these five values. Darul Hikmah Boarding School, one of the IBS built by DIBS alumni, for example, also teaches these five values to students, as a foundation life on IBS and off-campus. These values internalized through a multicultural based curriculum, considering that students study in these institutions varied in background, race, and nation. [46].

\subsection{The Strategies for Values Cultivation}

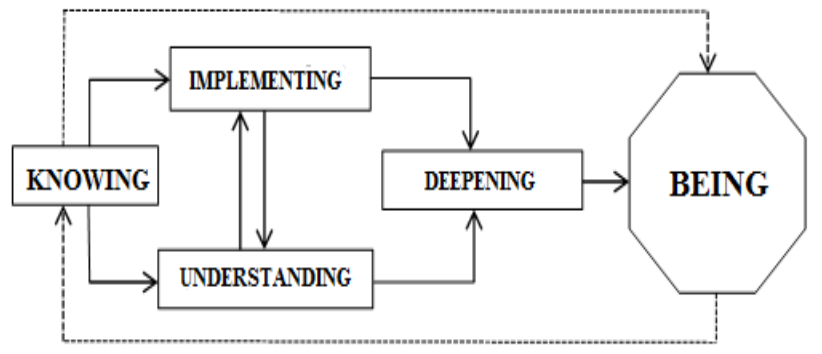

Figure 2. Model of values cultivation strategies in DIBS

Value cultivation is a significant activity in the organization [47] including educational organization. including an educational organization. All values set as organizational values must be taught to its members. Instilling these values requires a long process and hard work to make all members of the organization run it thoroughly, to align with the organization's vision and mission [48].

Educational organizations do the same thing. They have organizational values that must be implemented by their members [49]. DIBS, the process of embedding the five corporate values, as explained above, carried out through several stages, namely knowing, implementing, understanding, deepening, and being.

Knowing. Organizational values cultivation in DIBS begun with the Knowing strategy. It is the process of transferring the values to new and old students in DIBS in various ways. At this stage, the institution seeks to introduce the organization's values to new members exceptionally, and former members through several activities, whether annually, monthly, weekly, and daily. Several events picture the program of knowing the values in DIBS. The first week of school attendance in DIBS is a critical time for them to transfer the school values to the new and old students. This activity is called "Khutbatul Arsy" week. In this program, all DIBS leaders will deliver and explain the DIBS values implemented in the boarding school. This program allows all students to know values must be upheld and applied in their daily lives at the campus in particular and in society.

Introducing the values of this organization is not only done at the beginning of school attendance. It continues throughout the Islamic boarding school activities, starting from daily routine operations in the dormitory to lecturing in class - even extracurricular activities. It's also used as an appropriate means for them to introduce school values to students.

Introducing the values of school organizations to students requires a long process and must be carried out continuously. Therefore, the administrators of institutions and teachers must always work together to socialize these values continuously

Implementation. For introducing organizational values to students, requires them to carry out these values daily. The application of these values reflected in students' whole experience, ranging from getting up from their sleeping in the morning to going back to sleep. There is no single point in their lives that can separate from the five souls.

The institution provides a system that ensures the educational values have been introduced and implemented properly. Several organizational units were formed, such as a security section that controls student discipline and a language center section that manages language discipline.

The implementation of DIBS values reflected in the student's daily activities. They look very disciplined in carrying out school activities that arranged neatly, starting from mealtimes, school time, and rest time. Students carry out all events in an orderly manner. Anyone violates those values; they will get a reprimand and even an educative punishment $t$.

For students, the implementation of school values in DIBS is an obligation that must do. There is no reason for them to reject these values. Therefore they forced to do it, whether they understand it or not. According to them, to implement the school values, students do not have to understand it first but to try first. Coercion is an essential step for DIBS in instilling school values in students. According to them, through pressure, students will learn 
and understand educational values.

Understanding. According to DIBS, understanding school values is a long process. It is not enough for a year or two to understand these values. Therefore, the institution's strategy to understand these values to students is applying continuous socialization of values and repetition. Socialization of values is not only introduced at the beginning of the lecture but followed by learning in the classroom with a special subject of DIBS values. At the end of the semester, posttests are held. Before they take a vacation, caregivers gather students in the central building to brief on the organization's values.

Because understanding these school values is hard, they have to repeat the process of recognizing them simultaneously at the beginning and the end of the semester. Before they enter the new school year and after completing the semester exams, they are reassembled in the hall to re-oriented once more about the boarding school organization's values.

For DIBS to practice the five souls' values, they don't have to understand them first, but they must do it first. After they get used to doing it, they will appreciate the wisdom behind all the values taught. There may even be those who, as long as they are students at DIBS, do not fully understand these values but only follow them after leaving DIBS and finding wisdom.

Deepening. The deepening strategy aims to encourage students to deepen the values of boarding schools' five souls through several exercises that promote their knowledge of organizational values to a higher level. So students carry out these values not by force but by full of understanding and consciousness.

For implementing this strategy, the institution provides organizational units where students can be involved to become administrators. They are given the freedom to manage these units under the control of a central caregiver. Every week they report to the center's caregivers to report their difficulties and find solutions.

The deepening process needs to be carried out and must be followed by all students, primarily fifth-grade students and above. To explore the values of the five souls of boarding schools, they are directly involved in various boarding schools activities, such as being a member of a campus organization or rayon management. They play a full responsibility to take care of their juniors in various activities, including language development, writing skills, sports, arts, etc.

DIBS caregivers admit that understanding the values of the boarding school organization is not easy. Students must try to understand it through experience. Although initially, they don't understand them, they are obliged to carry out. After implementing it for several years, they finally realized and used it in their daily lives.

Being. This strategy is the most challenging strategy for both DIBS and students. Institutions force students to become people who have a role in society through community service programs. The institution requires students who have graduated from the Higher School level to be obliged to serve the community for one year without being paid. They can serve as teachers, entrepreneurs, developers, preachers, and others according to students' interests and talents. Therefore, the institution cooperates with several other institutions to become partners in which the students serve the community. After completing one year of service, they are only allowed to take the graduation certificate. The process of being can be successful if every member of the organization can apply the organization's values in their lives without compelling because they have become what is expected by the organization.

This study found several essential points about the values instilled in the students in the Islamic boarding schools and the strategies used in instilling these values in them. There are five fundamental values instilled by researched institutions in their students: sincerity, modesty, self-sufficient, Islamic brotherhood, and freedom. The founders of DIBS put these five soul values as a direction for members of the organization in carrying out their duties. The founders of DIBS plaid an essential role in building these values because they were the first people to have an idea of building the organization [50].

The five soul values are considered as an essential spirit for DIBS to run the organizations and used as the foundation of students' lives in the future. This research supports several previous studies which say that organizational values are the spirit of organizational development [51]. Therefore, the five souls instilled in students have become the spirit that underlies student activities both in the boarding school and when they have graduated from them. The soul of sincerity, for example, is highly emphasized because it is a starting point in all human activities. If someone does a job with sincerity, he will do it with full perseverance and honesty to improve performance [52]. Likewise, these five soul values have supported DIBS, able to run the organization well and economically.

The value planting strategy at DIBS is beneficial. In general, there are five steps taken by DIBS in instilling their organizational values; knowing, implementing, understanding, deepening, and being. The results of this study may be different from some theories that explain the inculcation of organizational values in general, which usually involves negotiating values and individual differences [53]. In DIBS, this value negotiation process does not exist for students because after they enter the institution, happy or not, they must accept these values without being allowed to argue or negotiate. Implementation of the five values is more forceful than negotiating. If they don't agree, they have to get out. However, this does not mean that coercive methods are not justified. Because some previous researches also suggested that coercive method effective for instilling ethical values in family accompanied by communication model [54], as 
happened in the Indies [55] and America, even though controversial [56], [57]. This study also accepts Mohamed et al. [2] research findings, which confirmed that the success of ethical values teaching in educational institutions is performed in three processes: knowledge, habits, and attitude. Besides, this study rejects research that says that traditional organizational power bases are not effective in promoting organizational ethics and performance [58].

\section{Conclusions}

From the discussion above concluded that each boarding school has specific organizational values instilled in its members for generations. Because of these values, Islamic boarding schools can exist and are in demand by the community. The organizational values can effectively maintain the continuity of the organization over time. That is why every Islamic educational institution strives to preserve these values through various formal and informal activities.

DIBS has five organizational values that have been formed and established by its founders since the founding of the institution, namely the sincerity, simplicity, independence, Islamic brotherhood, and freedom. The five values are then taught from generation to generation through strategic stages. DIBS began to instill its organizational value by introducing it through various activities ranging from formal and non-formal teaching. Students are required to carry out the five values in daily life. Deepening activities bring students to understand more about these values and become someone aspired by the institution.

\section{Limitation and Recommendation}

This research is only limited in understanding the educational values embedded by IDBS to students and their planting strategies. However, the researcher has not discussed the factors that influence the success of DIBS in instilling educational and organizational values. This issue is essential to study, given the success of this institution in instilling these values has been tested. Therefore, researchers think certain internal and external factors influence the success of this institution to instill the values of its organization to all members of the organization, including students, teachers, and employees.

Further research on these issues should be conducted to understand the requirements that must meet the inculcation of educational organization values. If theories about these issues are adequate, quantitatively measuring the most dominant factor can be done. However, if the argument is still debatable, subsequent researchers can do it qualitatively to find other factors that may not provide in detail in previous studies.

\section{Acknowledgement}

The researcher would like to thank the State Islamic University of Maulana Malik Ibrahim of Malang to facilitate and fund researchers in completing this research.

\section{REFERENCES}

[1] L. Groat and L. Stern, "Cultivating organizational values: A new model for workplace planning," J. Qual. Particip., vol. 23 , no. 5, p. 17, 2000.

[2] S. Mohamed, S. Sidek, N. Kudus, and M. Abu Hassan, "The cultivation of ethics and moral values among Malaysian university students: A case study at a Malaysian Technical University," J. Eng. Appl. Sci., vol. 12, no. 5, pp. 1218-1224, 2017.

[3] D. J. Willower, "Values, valuation and explanation in school organizations," J. Sch. Leadersh., vol. 4, no. 5, pp. 466-483, 1994, doi: https://doi.org/10.1177/105268469400400502.

[4] G. M. Almerico, "Building Character through Literacy with Children's Literature.," Res. High. Educ. J., vol. 26, 2014.

[5] A. Madkur and A. M. Albantani, "Instilling Islamic Values in Foreign Language Teaching: An Indonesian Context," 2017.

[6] J. Zajda, "Values education," Encycl. Educ. Theory Philos. Thousand Oaks CA Sage, 2014.

[7] A. Abdullah, "Instilling Values Character Education Through Playing Role Model in Learning History," 2016.

[8] M. Popper and R. Lipshitz, "Installing mechanisms and instilling values: the role of leaders in organizational learning," Learn. Organ., 2000.

[9] H. S. Ruchlin, N. L. Dubbs, M. A. Callahan, and M. J. Fosina, "The role of leadership in instilling a culture of safety: lessons from the literature," J. Healthc. Manag., vol. 49, no. 1, p. 47, 2004.

[10] Y. Allaire and M. E. Firsirotu, "Theories of organizational culture,” Organ. Stud., vol. 5, no. 3, pp. 193-226, 1984, doi: https://doi.org/10.1177/017084068400500301.

[11] L. Smircich, "Concepts of culture and organizational analysis," in The Antrhopology of Organization, Routledge, 2017, pp. 255-274.

[12] A. M. Pettigrew, "On studying organizational cultures," Adm. Sci. Q., vol. 24, no. 4, pp. 570-581, 1979.

[13] F. C. Steward, M. O. Mapes, and K. Mears, "Growth and organized development of cultured cells. II. Organization in cultures grown from freely suspended cell," Am. J. Bot., vol. 45 , no. 10 , pp. $705-708,1958$.

[14] C. E. Connelly and E. K. Kelloway, "Predictors of employees' perceptions of knowledge sharing cultures," Leadersh. Organ. Dev. J., 2003.

[15] V. Sathe, "Culture and related corporate realities: Text, cases, and readings on organizational entry, establishment, and 
change.” Richard D Irwin., 1985.

[16] B. Van Gorp, "The constructionist approach to framing: Bringing culture back in," J. Commun., vol. 57, no. 1, pp. 60-78, 2007.

[17] S. M. Davis, "Managing Organizational culture," Cambridge Mass: Bellinger Publishing Company, 1984.

[18] C. H. Turner, Organizational culture: How to Generate Organizational Strength and Lasting Commercial Advantage. London: Judy Piatkus, 1994.

[19] E. H. Schein, Organizational culture and leadership, vol. 2. John Wiley \& Sons., 2010.

[20] L. C. Harris and E. Ogbonna, "Employee responses to culture change efforts," Hum. Resour. Manag. J., vol. 8, no. 2, pp. 78-92, 1998.

[21] L. S. Paine, "Managing for organizational integrity," Harv. Bus. Rev., vol. 72, no. 2, pp. 106-117, 1994.

[22] A. L. Holten and S. O. Brenner, "Leadership style and the process of organizational change," Leadersh. Organ. Dev. J., vol. 36 , no. 1, pp. 2-16, 2015.

[23] W. G. Tierney, "Organizational culture in higher education: Defining the essentials," J. High. Educ., vol. 59, no. 1, pp. 2-21, 1988.

[24] P. Hallinger and K. Leithwood, "Culture and educational administration A case of finding out what you don't know you don't know," J. Educ. Adm., vol. 34, no. 5, pp. 98-116, 1996.

[25] A. T. Masland, "Organizational culture in the study of higher education," Rev. High. Educ., vol. 8, no. 2, pp. 157-168, 1985.

[26] Z. Dhofier, "The Pesantren Tradition: A Study of the Role of the Kyai in the Maintenance of the Traditional Ideology of Islam in Java.," 2014.

[27] F. M. Siregar, "Religious leader and charismatic leadership in Indonesia: the role of Kyai in Pesantren in Java," $J$. Kawistara, vol. 3, no. 2, 2013.

[28] M. L. Fauzi, "Traditional Islam in Javanese society: The roles of kyai and pesantren in preserving Islamic tradition and negotiating modernity," J. Indones. Islam, vol. 6, no. 1, pp. 125-144, 2012.

[29] P. Baxter and S. Jack, "Qualitative case study methodology: Study design and implementation for novice researchers," Qual. Rep., vol. 13, no. 4, p. '544-559, 2008.

[30] D. Masqon, Buku Profil Pondok Modern Gontor. Ponorogo: Gontor Press, 2015.

[31] N. Carter, D. Bryant-Lukosius, A. DiCenso, J. Blythe, and A. J. Neville, "The use of triangulation in qualitative research.," in Oncology nursing forum, 2014, vol. 41, no. 5.

[32] M. Oliver-Hoyo and D. Allen, "The Use of Triangulation Methods in Qualitative Educational Research.," J. Coll. Sci. Teach., vol. 35, no. 4, 2006.

[33] M. Huberman and M. B. Miles, The qualitative researcher's companion. Sage, 2002.

[34] J. W. Creswel, Research design: Qualitative, quantitative, and mixed methods approaches. Los angeles: University of Nebraska-Lincoln, 2009.

[35] T. E. Becker, "Integrity in organizations: Beyond honesty and conscientiousness," Acad. Manage. Rev., vol. 23, no. 1, pp. 154-161, 1998.

[36] Y. Fassin and M. Buelens, "The hypocrisy-sincerity continuum in corporate communication and decision making," Manag. Decis., 2011, doi: https://doi.org/10.1108/00251741111126503.

[37] S. Xiaohua Chen, M. H. Bond, B. Chan, D. Tang, and E. E. Buchtel, "Behavioral manifestations of modesty," $J$. Cross-Cult. Psychol., vol. 40, no. 4, pp. 603-626, 2009, doi: https://doi.org/10.1177/0022022108330992.

[38] M. S. Chung, "A study on the modesty in clothing and clothing values of male and female university students," $J$. Korean Soc. Cloth. Text., vol. 8, no. 1, pp. 85-94, 1984.

[39] M.-A. Suizzo, "Parents' goals and values for children: Dimensions of independence and interdependence across four US ethnic groups," J. Cross-Cult. Psychol., vol. 38, no. 4, pp. 506-530, 2007.

[40] C. Raeff, "European-American parents' ideas about their toddlers' independence and interdependence," J. Appl. Dev. Psychol., vol. 21, no. 2, pp. 183-205, 2000.

[41] M. Killen and C. Wainryb, "Independence and interdependence in diverse cultural contexts," New Dir. Child Adolesc. Dev., vol. 2000, no. 87, pp. 5-21, 2000.

[42] M. A. Clawson, Constructing brotherhood: Class, gender, and fraternalism. Princeton University Press, 2014.

[43] R. D. Cooter, "Freedom, Creativity, and Intellectual Property," NYUJL Lib., vol. 8, p. 1, 2013.

[44] W. DiPietro, "Freedom, boldness, and economic creativity," Knowl. Technol. Policy, vol. 15, no. 4, pp. 37-45, 2003.

[45] S. Ellison, "Performance Is... Freedom," Int. Rev. Qual. Res., vol. 3, no. 2, pp. 187-188, 2010.

[46] A. Muhajir, N. Naim, A. Z. Fitri, and A. Safi'i, "Approach to the Development of Multicultural Education Curriculum in Darul Hikmah Modern Islamic Boarding School Tulungagung, Indonesia," Univers. J. Educ. Res., vol. 8, no. 5, pp. 1842-1847, 2020, doi: 10.13189/ujer.2020.080520.

[47] R. Barrett, Building a values-driven organization. Routledge, 2006.

[48] J. Schaubroeck, S. S. K. Lam, and S. E. Cha, "Embracing transformational leadership: Team values and the impact of leader behavior on team performance.," J. Appl. Psychol., vol. 92, no. 4, pp. 1020-1030, 2007, doi: 10.1037/0021-9010.92.4.1020.

[49] P. Scott, "Challenges to academic values and the organization of academic work in a time of globalization," High. Educ. Eur., vol. 28, no. 3, pp. 295-306, 2003.

[50] E. H. Schein, "The role of the founder in creating organizational culture," Organ. Dyn., vol. 12, no. 1, pp. 13$28,1983$.

[51] V. Kinjerski and B. J. Skrypnek, "Creating organizational conditions that foster employee spirit at work," Leadersh. 
Organ. Dev. J., 2006.

[52] C. L. Jurkiewicz and R. A. Giacalone, "A values framework for measuring the impact of workplace spirituality on organizational performance," J. Bus. Ethics, vol. 49, no. 2, pp. 129-142, 2004.

[53] M. W. Grojean, C. J. Resick, M. W. Dickson, and D. B. Smith, "Leaders, Values, and Organizational Climate: Examining Leadership Strategies for Establishing an Organizational Climate Regarding Ethics," J. Bus. Ethics, vol. 55, no. 3, pp. 223-241, Dec. 2004, doi: 10.1007/s10551-004-1275-5.

[54] Y. Hendra and R. Priadi, "Family Communication Model in Forming Pious Children," Bp. Int. Res. Crit. Inst.-J. BIRCIJ., vol. 2, no. 1, pp. 28-38, 2019.
[55] V. Saxena, "Quality Issues in School Education: Towards Compulsory Inculcation of Value Education in India," Soc. Res., vol. 3, no. 1, pp. 51-62, 2015.

[56] J. R. Lott Jr, "Why is Education Publicy Provided-A Critical Survey," Cato J, vol. 7, p. 475, 1987.

[57] D. Tyack, "Ways of seeing: An essay on the history of compulsory schooling," Harv. Educ. Rev., vol. 46, no. 3, pp. 355-389, 1976, doi: https://doi.org/10.17763/haer.46.3.v73 405527200106v.

[58] A. Nygaard, H. Biong, R. Silkoset, and R. E. Kidwell, "Leading by Example: Values-Based Strategy to Instill Ethical Conduct," J. Bus. Ethics, vol. 145, no. 1, pp. 133139, Sep. 2017, doi: 10.1007/s10551-015-2885-9. 